\title{
Short communication: Drying-off practices and use of dry cow therapy in Finnish dairy herds
}

\author{
M. J. Vilar, ${ }^{1}$ M. Hovinen, H. Simojoki, and P. J. Rajala-Schultz \\ Department of Production Animal Medicine, Faculty of Veterinary Medicine, University of Helsinki, Saarentaus 04920 Finland
}

\begin{abstract}
The objective of this study was to survey drying-off practices and use of dry cow therapy (DCT) in Finland through an online questionnaire. The questionnaire was accessible to all dairy farmers of the Finnish dairy herd recording system in 2016 (approximately 5,400 farms). In total, 715 dairy producers across the country, representative of the Finnish dairy industry, participated in the survey. Cows were dried off gradually in most of the farms. Most farms (78\%) reported using selective DCT, whereas $9 \%$ of farms did not use any DCT, and $13 \%$ of farms applied blanket DCT. A significant trend was observed with increasing herd size and proportion of farms using blanket DCT. Percentage of farms using blanket DCT was also higher in farms with automatic milking system. Farmer's own experience was the most commonly reported reason for choosing a particular approach to DCT. Microbiological testing of milk samples at dry-off was the preferred method of selecting cows for DCT; 82 and $64 \%$ of farms using selective and blanket DCT approach, respectively, reported testing milk samples before treatment. The second most common criteria for using antibiotic DCT were clinical mastitis history and high somatic cell count. A high number of farms using selective DCT reported treating only up to one-fourth of their cows at dry-off. Information acquired on drying-off practices in Finland allows for future monitoring of prudent antimicrobial usage at dry-off.
\end{abstract}

Key words: dry cow therapy, drying-off practices, selective dry cow therapy

\section{Short Communication}

Dry cow management is important for dairy cow health and welfare, milk production, and therefore for the profitability of dairy farms (Dingwell et al., 2003; Bradley and Green, 2004). The actual drying-off pro-

Received March 14, 2018.

Accepted April 6, 2018.

${ }^{1}$ Corresponding author: maria.vilar@helsinki.fi cedures, such as whether cows are dried off abruptly or gradually by reducing milking frequency or restricting feed intake (or both), differ between herds and countries. Antibiotic dry cow therapy (DCT), however, is an important part of most mastitis control programs worldwide. Dry cow therapy aims to reduce prevalence of IMI by eliminating existing IMI at dry-off and preventing new IMI from occurring during the dry period. The IMI during the dry period increases the risk of clinical mastitis in the first weeks of subsequent lactation (Pieper et al., 2013). The DCT can be either administered to all quarters of all cows (blanket DCT) or given to treat quarters or cows with a diagnosed or suspected IMI (selective DCT). In addition, internal teat sealants (ITS), which are used to mimic the protective effects of the keratin plug, can be used alone or in combination with antibiotic DCT at dry-off to prevent IMI and clinical mastitis (Cameron et al., 2014; Krömker et al., 2014). In some countries, blanket DCT has been recommended at dry-off for decades; however, recently preventive use of antimicrobials has been increasingly questioned and criticized. Development of antimicrobial resistance in bacteria is currently viewed as the most serious global public health threat (WHO, 2014), and prudent use of antimicrobials in human and veterinary medicine, as well as in agriculture, is emphasized (EMA/CVMP, 2015). Prophylactic use of antimicrobials should be restricted and susceptibility of pathogens ensured before treatment (European Commission, 2011; FAO, 2016). Also, recently, the European Commission Notice 299/04 recommended avoiding routine treatment of cows at dry-off (European Commission, 2015). The success of selective DCT and the effect on udder health depends on the accuracy [i.e., sensitivity and specificity of the selection procedure of the infected quarters/cows (Scherpenzeel et al., 2016)]. Identification of cows or quarters (or both) needing treatment at dry-off can be based on different criteria [e.g., individual cow SCC data and clinical mastitis history (Bradley et al., 2010; Rajala-Schultz et al., 2011), or on-farm milk culturing (Cameron et al., 2013)]. In recent years, in some countries, such as in the Netherlands and Germany, selective DCT (Scherpenzeel et al., 2016) and 
use of ITS (Krömker et al., 2014) have been promoted as an alternative to blanket DCT. However, a recent study reported that in Germany, $79.6 \%$ of commercial farms used blanket DCT, and $64.9 \%$ of all antibiotic DCT were carried out without previous bacteriological examination (Bertulat et al., 2015). Traditionally, the use of DCT in Nordic dairy farms has been limited to selective DCT (Ekman and Østerås, 2003). Nevertheless, knowledge and statistics about the current use of DCT and drying-off practices in general in Finland are missing. Therefore, the objectives of the present study were to (1) describe the drying-off practices and how common the use of DCT in Finnish dairy herds is, and (2) evaluate the associations between the drying-off practices and the farm characteristics and management practices.

We conducted a survey about farm characteristics and dry cow management practices. An online survey was accessible to all dairy farmers in the Finnish dairy herd recording system in 2016 (approximately 5,400 farms). The questionnaire was designed using close-ended questions, and when necessary open-ended questions were used for clarification purposes. Questions were grouped by topic: (1) general farm information, (2) drying-off practices, (3) antibiotic dry cow therapy, and (4) use of ITS. Type of DCT was the only obligatory question, and depending on the chosen answer, a new group of questions opened; therefore, if the responder selected blanket DCT as the option used in their farm, only a set of questions regarding the use of blanket DCT became available. The questionnaire was pre-tested with veterinarians and farmers. Pre-testing showed that the questionnaire took 10 to $20 \mathrm{~min}$ to complete and resulted in minor changes in the questionnaire format. The questionnaire was launched in collaboration with the main Finnish dairy processing company (a co-operative collecting milk from $85 \%$ of Finnish dairy farms) and the organization responsible for the official milk recording data system. It was accessible in both official languages, Finnish and Swedish. To encourage participation, the Dillman survey guidelines were followed (Dillman et al., 2014). Briefly, an introduction letter (both an electronic and a paper version), an invitation, and 2 follow-up reminders with the link to the web survey were sent to all dairy farmers. The online version of the questionnaire was open for participation between January and May 2017, and a paper version was also available per request during the same period of time. In addition, we organized a raffle among all respondents to increase the response rate. The online version of the questionnaire was designed in the E-lomake 3 browser (Eduix Oy, Tampere, Finland), which allows a direct transfer of data into a spreadsheet or statistics software. Thus, data collected from the online survey were exported to Excel (Microsoft Corp., Redmond, WA) for quality checks and cleaning. The software package IBM SPSS Statistics for Windows (version 24.0, IBM Corp., Armonk, NY) was used to explore possible associations between drying-off practices and different variables at farm level. The Pearson chi-squared test was used to investigate potential associations between categorical variables. The Cochran-Armitage trend test was performed to evaluate differences between the use of DCT and use of ITS across different herd sizes, rolling herd average milk production, and differences between use of DCT and use of ITS within milking systems.

In total, 715 dairy farmers ( $13.2 \%$ out of 5,400 farms) across the country participated in the survey; 714 farmers filled out the online questionnaire and 1 filled out the paper version. Based on their responses, $97.8 \%$ of the farms were conventional and $2.2 \%$ were organic farms. The proportion of farms with pipeline milking in tiestalls, parlor, and automatic milking system (AMS) was $54.5,23.2$, and $22.3 \%$, respectively. The reported herd sizes were small, $34 \%$ of farms having less than 30 cows and $38.5 \%$ of farms with between 30 and 60 cows. Only $27.5 \%$ of the farms had more than 60 cows. Rolling herd average milk production was reported to be less than $8,000 \mathrm{~kg}$ per cow per year in $6.4 \%$ of responding farms, and more than $10,000 \mathrm{~kg}$ per cow per year in $37.5 \%$ of farms. Based on their responses, $66.1 \%$ of the farms had bulk tank milk SCC under 150,000 cell/ $\mathrm{mL}$. The reported farm characteristics indicate that the responding farms were representative of current Finnish dairy industry (LUKE, Natural Resource Institute Finland, 2017).

Cows were dried off gradually in $96.1 \%$ of the responding farms, and in $86.1 \%$ of the farms, cows were reported to produce $15 \mathrm{~kg} / \mathrm{d}$ or less at dry-off. The ration was changed and feed intake restricted before the dry period in $87.2 \%$ of the farms. The length of the dry period was reported to be between 6 and 8 wk in $79 \%$ of the farms, and over $8 \mathrm{wk}$ in $19.0 \%$ of the farms. However, the average length of a dry period registered in the Finnish dairy herd recording system is higher (67 d).

Selective DCT was the most common $(78 \%$ farms, $558 / 715)$ practice when drying off cows, whereas $8.7 \%$ $(62 / 715)$ of farms did not use antibiotic DCT at all and $13.3 \%(95 / 715)$ of farms applied blanket DCT. Table 1 shows the number (and percentage) of farms that reported using different approaches to DCT and farm characteristics and other management practices. In Nordic countries, application of selective DCT rather than blanket DCT has been recommended while emphasizing the importance of preventive measures to control IMI (Ekman and Østerås, 2003). For example, in Denmark, DCT is only recommended if contagious 
mastitis is present in the herd (Katholm and Bennedsgaard, 2013). In addition, in all Nordic countries, antimicrobials are available only by veterinary prescription, and it is noteworthy that veterinarians are not allowed to profit from selling antibiotics. Although the prophylactic use of antimicrobials in food animal production has raised concerns about the development of resistance and their effect on public health, in some countries antibiotics are given at dry-off to all cows regardless of the presence of IMI. For example, the majority of dairy producers in Canada, Germany, and United States, among other countries, apply blanket DCT (Dufour et al., 2012; Bertulat et al., 2015; USDA, 2016). The Netherlands, where blanket DCT had been widely implemented, has recently banned prophylactic use of antimicrobials at dry-off (Santman-Berends et al., 2016).

A significant trend (Cochran-Armitage test, $P=$ 0.011) between increasing milk production and proportion of farms using blanket DCT was observed (Figure 1). Also, in the current survey, a significant trend (Cochran-Armitage test, $P<0.0001$ ) between increasing herd size and proportion of farms using blanket DCT was observed (Figure 2), e.g., $9.5 \%$ of small farms $(<30$ cows $)$ vs. $23 \%$ of the bigger farms ( $>60$ cows) reported using blanket DCT. The use of blanket DCT in larger herds is common in some countries such as
United States, where blanket DCT is used in $94.2 \%$ of farms with more than 500 cows versus $77.5 \%$ of farms with less than 100 cows (USDA, 2016), and Germany, where the $79.6 \%$ of farms with an average of 97.5 cows used blanket DCT (Bertulat et al., 2015). The increase of herd sizes has been facilitated by new technologies and mechanization (Andrews and Poole, 2004). In the current study, the percentage of farms using blanket DCT was higher in farms with AMS $(23.4 \%)$ than in farms with parlor $(12.2 \%)$ or pipeline milking $(9.9 \%$; Cochran-Armitage test, $P<0.0001$, Figure 3$)$. The association between AMS and use of blanket DCT could also partly be explained because the distribution of mastitis pathogens has changed with the use of AMS, as reported by Østerås (2013). For example, the odds of having Streptococcus agalactiae increased by 3.9 and Streptococcus dysgalactiae by 1.2 when comparing AMS herds to non-AMS herds (Østerås, 2013). A considerable amount of milk is nowadays produced by cows in AMS in Nordic countries. In Finland, up to $30 \%$ of milk is produced in farms with AMS (Sigurdsson et al., 2017).

The reported approach to DCT in a farm had been in use for more than $5 \mathrm{yr}$ in $65.5 \%$ of the responding farms. Actually, of those farms applying selective DCT, most (69.8\% of farms) had used this approach for more than $5 \mathrm{yr}$, whereas blanket DCT had been in use for more

Table 1. Distribution of farms, number (and percentage in parentheses) that use different approaches to antibiotic dry cow therapy (DCT) by farm characteristics and management practices $^{1}$

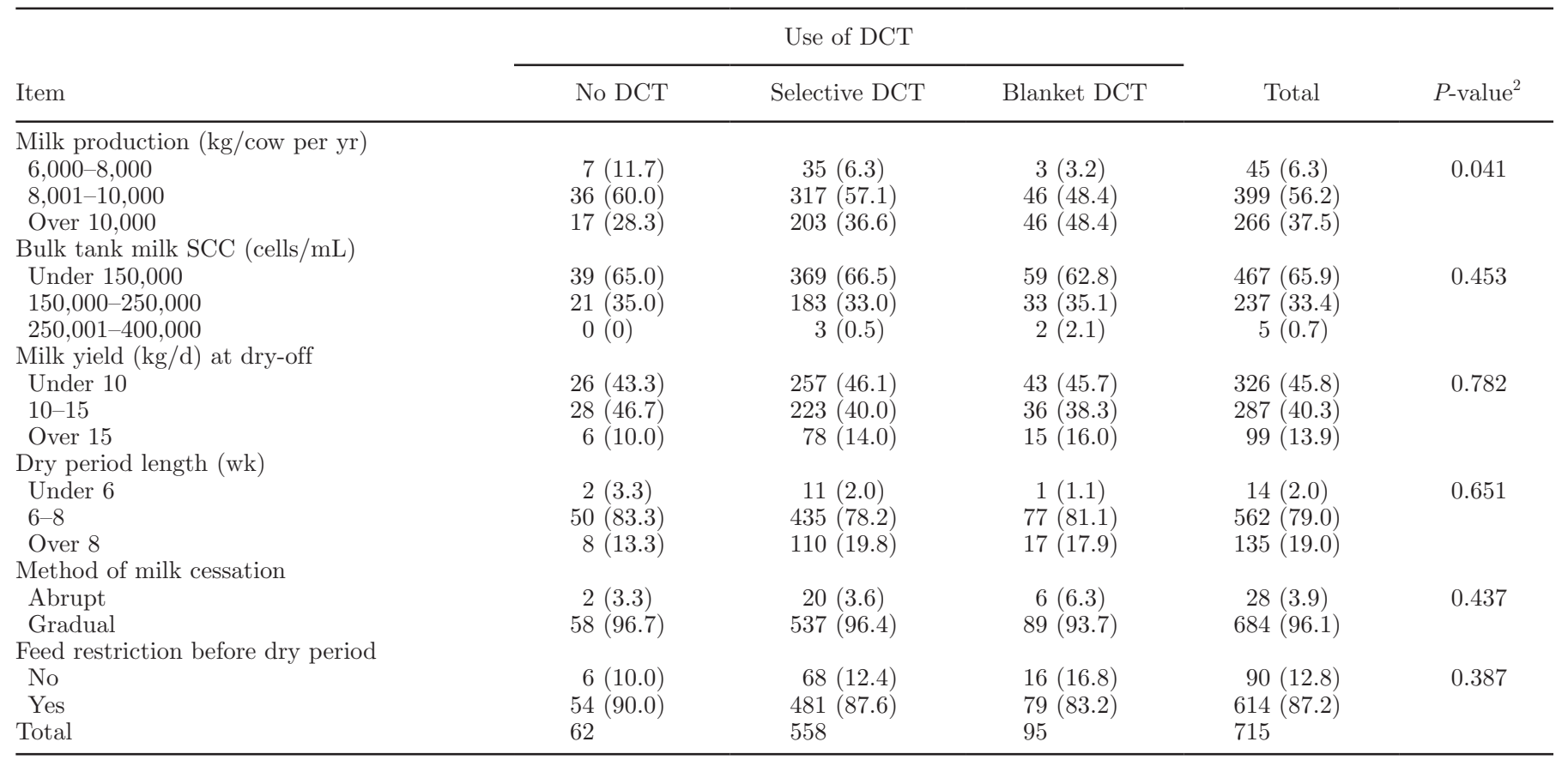

${ }^{1}$ The percentages indicate the proportions within the DCT groups.

${ }^{2} P$-values reflect comparisons between the DCT groups, tested with the Pearson $\chi^{2}$ test. 


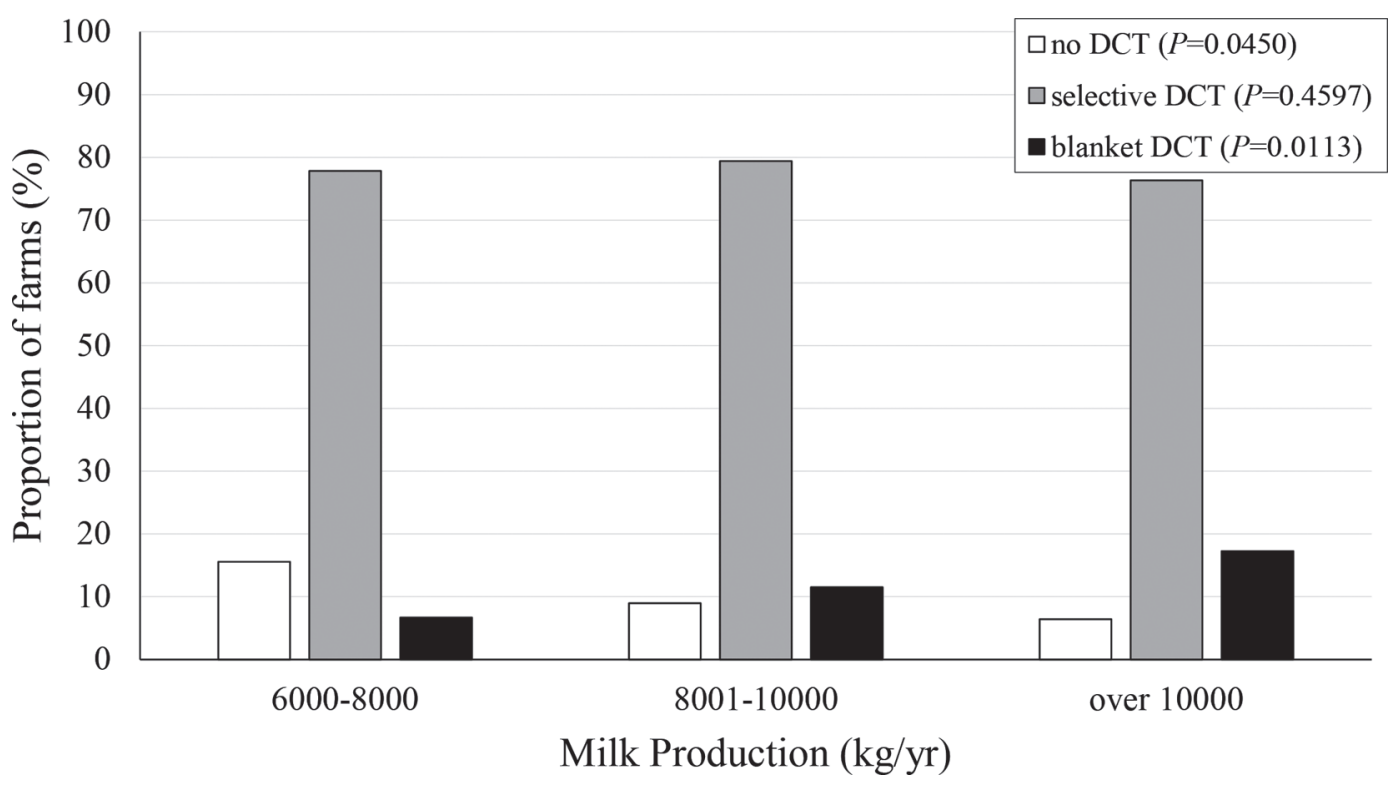

Figure 1. Distribution of Finnish dairy farms that use different approaches to dry cow therapy (DCT), grouped by the rolling herd milk production. A trend was observed between increasing milk production and proportion of farms using blanket DCT (Cochran-Armitage test, $P$ $=0.011$ ), and between decreasing milk production and no DCT (Cochran-Armitage test, $P=0.045$ ).

than $5 \mathrm{yr}$ in $41.4 \%$ of farms and less than $5 \mathrm{yr}$ in $58.6 \%$ of farms. The fact that over half of these farms have started using blanket DCT during the last 5 yr might be explained by the recent changes in the distribution of mastitis pathogens and re-emergence of Strep. agalactiae in Finnish dairy farms. In Finland, campaigns against bovine mastitis have been able to decrease the herd prevalence of mastitis (defined as SCC $\geq 300,000$ cell $/ \mathrm{mL}$ at least in one quarter), from $47.8 \%$ in the 1980s and 1990s (Myllys et al., 1998) to $30.6 \%$ in 2001 (Pitkälä et al., 2004), and as a secondary consequence, relative proportions of pathogens have changed over that time. The percentages of Staphylococcus aureus, Strep. agalactiae, CNS, and Corynebacterium bovis in

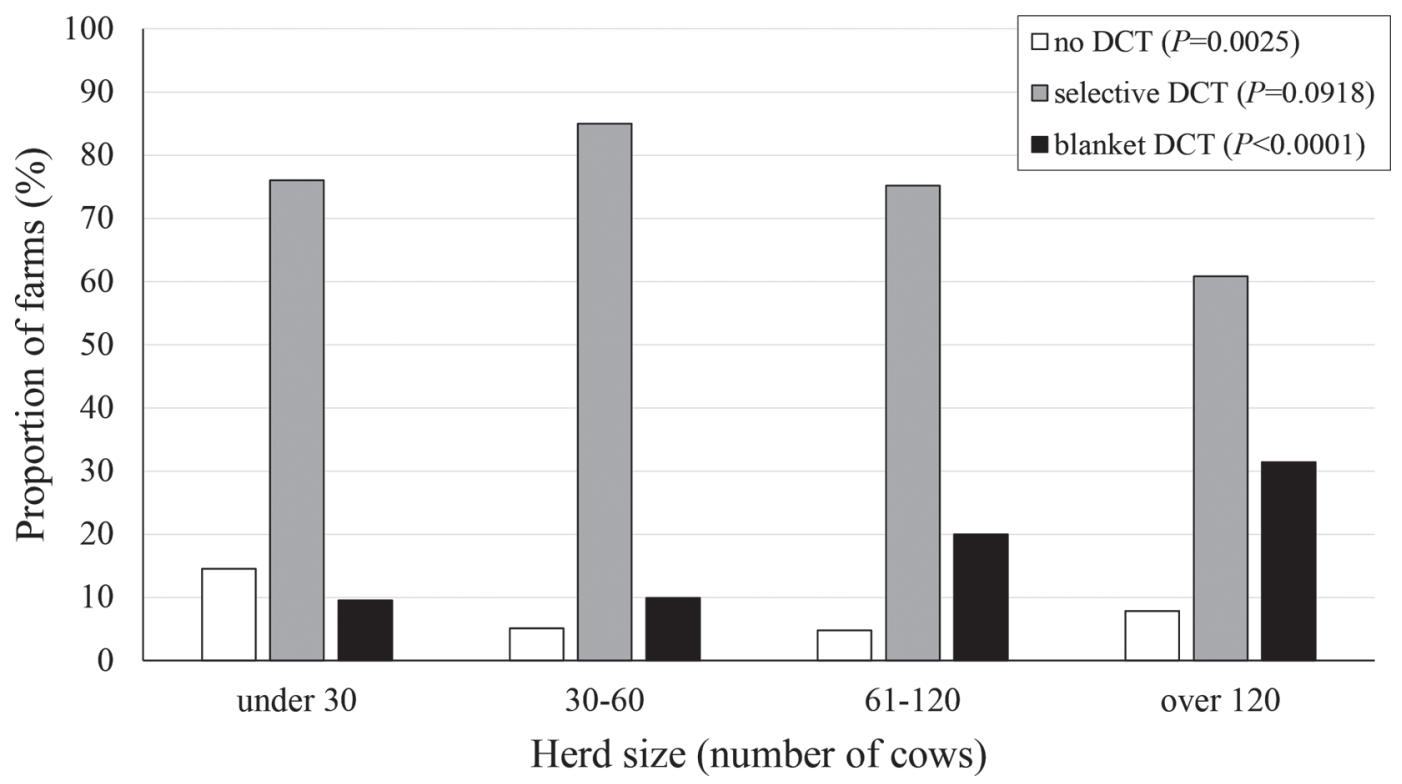

Figure 2. Distribution of Finnish dairy farms that use different approaches to dry cow therapy (DCT), grouped by the herd size. A trend was observed between increasing herd size and proportion of farms using blanket DCT (Cochran-Armitage test, $P<0.0001$ ), and between decreasing herd size and no DCT (Cochran-Armitage test, $P=0.002$ ). 
milk samples from subclinical and clinical mastitis with positive bacterial findings increased from 2004-2006 to 2010-2012. For example, the proportion of Staph. aureus increased from $15.9 \%$ to $21.1 \%$, Strep. agalactiae from $0.2 \%$ to $0.4 \%$, CNS from $21.1 \%$ to $43.3 \%$, and $C$. bovis from $2.2 \%$ to $7.2 \%$ (Koivula et al., 2007; Vakkamäki et al., 2017), even though it is important to note that different methodologies were used in these studies, making direct comparison challenging. Bacteria such as Staph. aureus and Strep. agalactiae have higher cure rates at dry-off than in lactation (O'Rourke and Baggot, 2004; Bradley et al., 2010), and this could be the reason why the application of blanket DCT was selected to control mastitis.

The farmer's own experience was the reason most commonly reported (64.4\% of farms) for choosing a particular approach to DCT, followed by veterinary advice (34.8\% of farms) and other farmers' experience or advice $(0.8 \%$ of farms). However, of those farms that applied blanket DCT, the proportions of farms that selected the approach based on their own experience and on veterinary advice were similar: $50.7 \%$ and $46.4 \%$, respectively. An indication for the use of blanket DCT recommended by veterinarians is likely high prevalence of mastitis caused by contagious pathogens in a herd. Finnish guidelines for the use of antimicrobials (Evira, Finnish Food Safety Authority, 2016) recommend postponing treatment of subclinical mastitis until dry-off. Good udder health was the most frequently reported reason $(62.3 \%)$ for the selected approach in farms that did not use any antibiotic DCT.

Bacteriological examination of milk samples from at least some cows at dry-off was carried out in $81.9 \%$ (457/558) and $64.2 \%(61 / 95)$ of farms that used selective DCT and blanket DCT, respectively. Milk from all cows was microbiologically examined at dry-off in $33.9 \%$ of the responding farms applying selective DCT. In Finland, bacteriological examination of milk samples is mostly carried out by using PCR in the laboratory of the major dairy processor (Vakkamäki et al., 2017). This PCR assay also tests for the presence of $\beta$-lactamase gene. These high percentages of farms that bacteriologically examined milk of cows at dry-off is likely a result of the Finnish guidelines that emphasize the importance of microbiological diagnosis before antimicrobial treatments are applied. In addition, analysis of milk samples was carried out significantly $(P=0.041)$ more often in farms with pipeline milking $(51.9 \%)$ than in farms with parlor $(25.4 \%)$ or AMS (22.7\%). Along with the bacteriological analysis of milk, common criteria to select cows for DCT were data on clinical mastitis history and high SCC $(61.3 \%$ of farms).

A high number of farms using selective DCT (71.5\%) reported treating only up to one-fourth of their cows at dry-off. Thorough knowledge of the individual cow clinical mastitis history, SCC records, or both has been reported to be a practical and valid criterion to identify

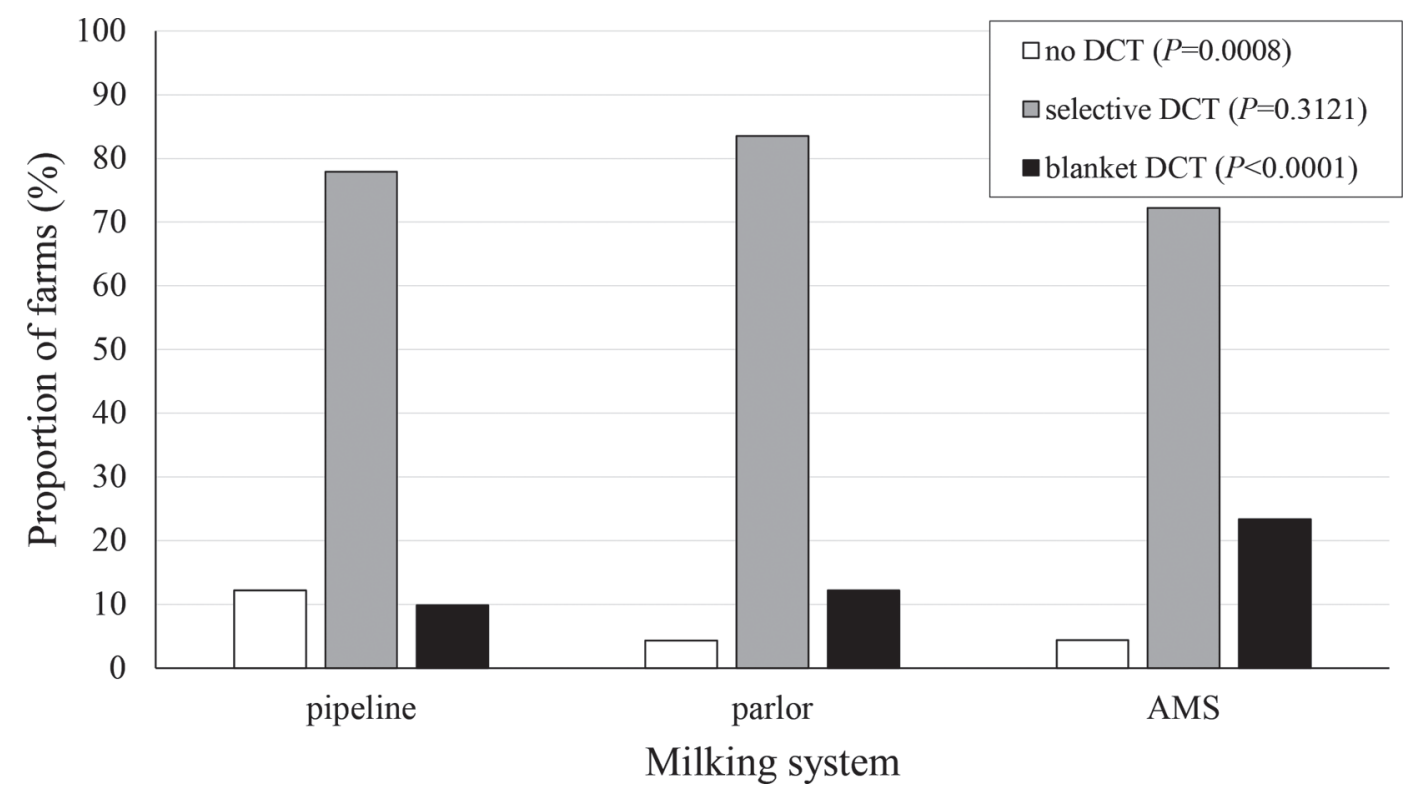

Figure 3. Distribution of Finnish dairy farms that use different approaches to dry cow therapy (DCT), grouped by milking system. The percentage of farms using blanket DCT was higher in farms with automatic milking systems (AMS) than in farms with parlor or pipeline milking (Cochran-Armitage test, $P<0.0001$ ). 
infected cows at dry-off (Torres et al., 2008). Thus, this knowledge could be the reason why $16.5 \%$ of farms using selective DCT treated cows without bacteriological examination of milk samples at dry-off. However, bacteriological culture of milk samples from cows, especially with elevated SCC, is highly recommended for a correct selection of cows and quarters to be treated with appropriate antibiotic DCT (Sampimon et al., 2008).

Regarding the use of ITS, 35\% out of the 709 responding farms reported to use ITS alone or in combination with antibiotic DCT. Of those farms using ITS, the $44.5 \%$ of farms applied it to up to one-fourth of their cows, and the proportion of farms applying it to all cows was $34.6 \%$. The main reported justification to use ITS was "other reasons" ( $81.1 \%$ of farms; e.g., to give extra protection, farmer had had a positive experience, reported presence of specific pathogens such as Staph. aureus, among other reasons). Similar to DCT, a significant trend (Cochran-Armitage test, $P<0.0001)$ was observed between increasing herd size and proportion of farms using ITS [e.g., $21.7 \%$ of small farms ( $<30$ cows $)$ vs. $49.7 \%$ of bigger farms $(>60$ cows $)$ reported using ITS]. Differences $(P<0.0001)$ were also detected between the percentage of farms using ITS in farms with AMS (49.0\%), with milking parlor (40.7\%) or pipeline milking $(24.8 \%)$.

The results of this survey confirm the traditionally common knowledge that the use of DCT in Finland is limited to treatment of selected cows. Majority of farms (78\%) reported using selective DCT or no DCT $(8.7 \%)$. Blanket DCT was most commonly used in farms with AMS. In addition, a high percentage of farms applying selective DCT (81.9\%) and blanket DCT $(64.2 \%)$ examined milk samples bacteriologically at the dry-off.

\section{ACKNOWLEDGMENTS}

The authors are grateful for the Valio Ltd. (Helsinki, Finland) and ProAgria (Vantaa, Finland) personnel for their collaboration with launching the survey and for all responding farmers for participation. Financial support was provided by the Walter Ehrström Foundation (Helsinki, Finland).

\section{REFERENCES}

Andrews, A. H., and A. Poole. 2004. Dairy farming. Pages 22-53 in Bovine Medicine. Diseases and Husbandry of Cattle. 2nd ed. A. H. Andrews, R. W. Blowey, H. Boyd, and R. G. Eddy, ed. Blackwell Science Ltd., United Kingdom.

Bertulat, S., C. Fischer-Tenhagen, and W. Heuwieser. 2015. A survey of drying-off practices on commercial dairy farms in northern Germany and a comparison to science-based recommendations. Vet. Rec. Open 2:e000068. https://doi.org/10.1136/vetreco-2014 -000068 .
Bradley, A. J., J. E. Breen, B. Payne, P. Williams, and M. J. Green. 2010. The use of a cephalonium containing dry cow therapy and an internal teat sealant, both alone and in combination. J. Dairy Sci. 93:1566-1577. https://doi.org/10.3168/jds.2009-2725.

Bradley, A. J., and M. J. Green. 2004. The importance of the nonlactating period in the epidemiology of intramammary infection and strategies for prevention. Vet. Clin. North Am. Food Anim. Pract. 20:547-568. https://doi.org/10.1016/j.cvfa.2004.06.010.

Cameron, M., G. P. Keefe, J. P. Roy, I. R. Dohoo, K. A. MacDonald, and S. L. McKenna. 2013. Evaluation of a 3M Petrifilm on-farm culture system for the detection of intramammary infection at the end of lactation. Prev. Vet. Med. 111:1-9. https://doi.org/10 .1016/j.prevetmed.2013.03.006

Cameron, M., S. L. McKenna, K. A. MacDonald, I. R. Dohoo, J. P. Roy, and G. P. Keefe. 2014. Evaluation of selective dry cow treatment following on-farm culture: Risk of postcalving intramammary infection and clinical mastitis in the subsequent lactation. J. Dairy Sci. 97:270-284. https://doi.org/10.3168/jds.2013-7060.

Dillman, D. A., J. D. Smyth, and L. M. Christian. 2014. Internet, Phone, Mail and Mixed-Mode Surveys: The Tailored Design Method. 4th ed. John Wiley \& Sons, Hoboken, NJ.

Dingwell, R. T., D. F. Kelton, and K. E. Leslie. 2003. Management of the dry cow in control of peripartum disease and mastitis. Vet. Clin. North Am. Food Anim. Pract. 19:235-265. https://doi.org/ 10.1016/S0749-0720(02)00072-5.

Dufour, S., I. R. Dohoo, H. W. Barkema, L. DesCôteaux, T. J. DeVries, K. K. Reyher, J. P. Roy, and D. T. Scholl. 2012. Manageable risk factors associated with the lactational incidence, elimination, and prevalence of Staphylococcus aureus intramammary infections in dairy cows. J. Dairy Sci. 95:1283-1300. https://doi.org/10.3168/ jds.2011-4711.

Ekman, T., and O. Østerås. 2003. Mastitis control and dry cow therapy in the Nordic countries. Pages 18-30 in 42nd Annual Meeting of National Mastitis Council, Fort Worth, TX. Natl. Mastitis Counc. Inc., Madison, WI.

EMA/CVMP. 2015. European Medicines Agency (EMA). Draft CVMP strategy on antimicrobials 2016-2020. Committee for Medicinal Products for Veterinary Use (CVMP). EMA/CVMP/209189/2015. Accessed Sep. 21, 2016. http://www.ema.europa.eu/ema/index .jsp?curl=pages /regulation/general/general_ content_001686 jsp\&mid=WC0b01ac05807a4e0d.

European Commission. 2015. Commission Notice: Guidelines for the prudent use of antimicrobials in veterinary medicine. No C 299/04. Off. J. Eur. Union C 299:7-26. http://eur-lex.europa.eu/legal -content/EN/ALL/?uri=OJ\%3AC\%3A2015\%3A299\%3ATOC.

European Commission. 2011. Commission's 2011 Action Plan against the rising threats from AMR. DGs: Health and Food Safety. Accessed Sep. 21, 2016. http://ec.europa.eu/dgs/health_food-safety/ amr/action_eu/index_en.htm

Evira, Finnish Food Safety Authority. 2016. Recommendations for the use of antimicrobials in the treatment of the most significant infectious diseases in animals (in Finnish). Helsinki. Accessed Aug. 22 2017. https://www.evira.fi/globalassets/tietoa-evirasta/julkaisut/ julkaisusarjat/elaimet/ mikrobilaakkeiden_kayttosuositukset_fi004.pdf.

FAO. 2016. Reducing the spread of antimicrobial resistance on our farms and in our food. Accessed Sep. 21, 2016. http://www.fao .org/news/story/en/item/433096/icode/.

Katholm, J., and T. W. Bennedsgaard. 2013. Results from the Danish milk quality campaign "our milk-A pure pleasure", on BTSCC mastitis treatments, dry cow therapy and dynamics of individual cow cell count from DHI samples. Pages 22-22 in The 29th NKVet Symposium: Mastitis-New Knowledge on Diagnosis and Control on Modern Dairy Farms, Reykjavik, Iceland.

Koivula, M., A. Pitkälä, S. Pyörälä, and E. A. Mäntysaari. 2007. Distribution of bacteria and seasonal and regional effects in a new database for mastitis pathogens in Finland. Acta Agric. Scand. Anim. Sci. 57:89-96.

Krömker, V., N. T. Grabowski, and J. Friedrich. 2014. New infection rate of bovine mammary glands after application of an internal 
teat seal at dry-off. J. Dairy Res. 81:54-58. https://doi.org/10 $.1017 /$ S0022029913000599.

LUKE, Natural Resource Institute Finland. 2017. Number of dairy cows by herd size. Accessed Apr. 6, 2017. http://statdb.luke.fi/ PXWeb/pxweb/fi/LUKE/LUKE__02\%20Maatalous__04\%20 Tuotanto__12\%20Kotielainten\%20lukumaara/03_Lypsylehmien _lukumaara_karjakokoluokka.px/?rxid=b865ace6-fa2e-4737-9664 $-\mathrm{d} 21 \mathrm{e} 80 \mathrm{~d} 8 \mathrm{f} 928$.

Myllys, V., K. Asplund, E. Brofeldt, V. Hirvelä-Koski, T. HonkanenBuzalski, J. Junttila, L. Kulkas, O. Myllykangas, M. Niskanen, H. Saloniemi, M. Sandholm, and T. Saranpää. 1998. Bovine mastitis in Finland in 1988 and 1995-Changes in prevalence and antimicrobial resistance. Acta Vet. Scand. 39:119-126.

O'Rourke, D. J., and J. D. Baggot. 2004. Antimicrobial therapy of mastitis. Pages 391-405 in Bovine Medicine: Diseases and Husbandry of Cattle. 2nd ed. A. H. Andrews, R. W. Blowey, H. Boyd, and R. G. Eddy, ed. Blackwell Science Ltd., Oxford, United Kingdom.

Østerås, O. 2013. The modern Nordic dairy farm (Key note). Page 4 in The 29th NKVet Symposium: Mastitis-New Knowledge on Diagnosis and Control on Modern Dairy Farms, Reykjavik, Iceland.

Pieper, J., M. Hoedemaker, and V. Krömker. 2013. Significance of the dry period for the development and prevention of new infections of the bovine mammary gland. Tierarztl. Prax. Ausg. G Grosstiere Nutztiere 41:315-324.

Pitkälä, A., M. Haveri, S. Pyörälä, V. Myllys, and T. Honkanen-Buzalski. 2004. Bovine mastitis in Finland 2001-Prevalence, distribution of bacteria, and antimicrobial resistance. J. Dairy Sci. 87:2433-2441. https://doi.org/10.3168/jds.S0022-0302(04)73366 $-4$.

Rajala-Schultz, P. J., A. H. Torres, and F. J. DeGraves. 2011. Milk yield and somatic cell count during the following lactation after selective treatment of cows at dry-off. J. Dairy Res. 78:489-499. https://doi.org/10.1017/S0022029911000690.
Sampimon, O. C., R. G. M. Olde Riekerink, and T. J. G. M. Lam. 2008. Prevalence of subclinical mastitis pathogens and adoption of udder health management practices on Dutch dairy farms: Preliminary results. Page 39-46 in Mastitis Control-From Science to Practice. Wageningen Academic Publishers, The Hague, the Netherlands.

Santman-Berends, I. M. G. A.. J. M. Swinkels, T. J. G. M. Lam, J. Keurentjes, and G. van Schaik. 2016. Evaluation of udder health parameters and risk factors for clinical mastitis in Dutch dairy herds in the context of a restricted antimicrobial usage policy. J. Dairy Sci. 99:2930-2939. https://doi.org/10.3168/jds.2015-10398.

Scherpenzeel, C. G. M., I. E. M. den Uijl, G. van Schaik, R. G. M. O. Riekerink, H. Hogeveen, and T. J. G. M. Lam. 2016. Effect of different scenarios for selective dry-cow therapy on udder health, antimicrobial usage, and economics. J. Dairy Sci. 99:3753-3764. https://doi.org/10.3168/jds.2015-9963.

Sigurdsson, S., E. Manninen, K. Nyman, T. Hettasch, K. Thunberg, H. Kromann, and H. H. Bentin. 2017. Automatic milking in Nordic countries, year 2016 (in Finnish). Maito Ja Me. Accessed Sep. 16, 2017. http://www.maitojame.fi/articles/automaattilypsy -pohjoismaissa-vuonna-2016/17290633.

Torres, A. H., P. J. Rajala-Schultz, F. J. DeGraves, and K. H. Hoblet. 2008. Using dairy herd improvement records and clinical mastitis history to identify subclinical mastitis infections at dry-off. J. Dairy Res. 75:240-247. https://doi.org/10.1017/S0022029908003257.

USDA. 2016. Dairy 2014, Milk Quality, Milking Procedures, and Mastitis in the United States, 2014. USDA-APHIS-VS-CEAHNAHMS. Fort Collins, CO. \#704.0916.

Vakkamäki, J., S. Taponen, A. M. Heikkilä, and S. Pyörälä. 2017. Bacteriological etiology and treatment of mastitis in Finnish dairy herds. Acta Vet. Scand. 59:33.

WHO. 2014. Antimicrobial resistance, Global report on surveillance 2014. Accessed Sep. 21, 2016. http://www.who.int/drugresistance/ documents/surveillancereport/en/. 